\title{
Studi Pertumbuhan Rumput Laut Jenis Kotoni (Eucheuma cottonii) dengan Menggunakan Metode Kurung Dasar dan Lepas Dasar di Perairan Geger, Bali
}

\author{
Andreas Pratama Togatorop a*, I Gusti Ngurah Putra Dirgayusa a, \\ Ni Luh Putu Ria Puspitha a \\ a Program Studi Ilmu Kelautan, Fakultas Kelautan dan Perikanan, Universitas Udayana, Kampus UNUD Bukit Jimbaran, Bali 80361, Indonesia \\ * Penulis koresponden. Tel.: +62-853-716-048-33 \\ Alamat e-mail: andreaas.pratama13@mail.com
}

Diterima (received) 19 Agustus 2016; disetujui (accepted) 5 Februari 2017; tersedia secara online (available online) 7 Februari 2017

\begin{abstract}
One of the factors that define the success of seaweed is the planting methods It self. It is important because the method will directly affect the seaweed production. The main problem faced by seaweed farmer is declining the production over years. There are several reasons causing that problem, including, predator, desease and environment degradation. The purpose of this research is investigating the effectiveness of two different seaweed planting methods with the respect to the seaweed growth rate. The two methods that mentioned previously are off bottom and off bottom bracket method. The two methods are basically simillar, the first method (off bottom) is a conventional method, on the other hand, the second method was given an additional nets in order to cover the off bottom construction. The space between each seaweed planting on two different methods are defined similar, which are 25 $\mathrm{cm}$. The initial planting weight was measured 100 grams. Observation was done for 42 days (6 week) and data collection was performed every 7 days on total of 10 individual seaweed each treatment. Absolute weight, daily growth rate, daily growth and specific growth rate are calculated. The data analysis will be done using $\mathrm{F}$ test at $\alpha=$ 0.05 (SPSS 12.0). The result found that the growth rate of seaweed (Eucheuma cottoni) under off bottom bracket was not significantly different compared to the off bottom method $(\alpha=0.476)$.
\end{abstract}

Keywords: growth; growth rate; Eucheuma cottonii; planting method

\begin{abstract}
Abstrak
Rumput laut merupakan tumbuhan laut yang memiliki nilai ekonomis yang penting. Salah satu faktorutama yang mendukung keberhasilan budidaya rumput laut agar menjaga ketersediaan produksinya agar tetap banyak ialah metode penanaman rumput laut itu sendiri. Permasalahan utama petani rumput laut ialah berkurangnya kuantitas rumput laut. Faktor penyebab kerusakan pada rumput laut ialah serangan predator. Tujuan dari penelitian ini ialah mengetahui efektivitas pertumbuhan rumput laut Eucheuma cottonii dengan dua metode penanaman berbeda. Budidaya rumput laut dilakukan dengan dua metode penanaman yang berbeda, yang pertama adalah metode penanaman lepas dasar dengan teknik penanaman yang mengikuti metode penanaman petani pada umumnya dan metode penanaman kurung dasar dengan tambahan jaring untuk menutupi rangkaian kontruksi penanaman. Jarak tanam masing - masing sampel rumput laut yaitu $25 \mathrm{~cm}$. Berat awal Eucheuma cottonii yaitu sebesar 100 gram. Waktu pemeliharaan selama 42 hari (6 minggu), dan pengumpulan data dilakukan setiap 7 hari sekali sebanyak 10 sampel rumput laut. Data pertumbuhan rumput laut akan dianalisis dengan uji statistik (uji F) pada $\alpha=5 \%$. Hasil penelitian yang diperoleh menunjukkan bahwa pertumbuhan Eucheuma cottonii dengan menggunakan metode penanaman kurung dasar tidak memberikan hasil pertumbuhan yang berbeda secara nyata dengan metode penanaman lepas dasar. Nilai signifikan yang dihasilkan sebesar 0.476 pada taraf kepercayaan sebesar $5 \%$.
\end{abstract}

Kata Kunci: pertumbuhan; laju pertumbuhan, Eucheuma cottonii; metode penanaman 


\section{Pendahuluan}

Rumput laut (seaweed) merupakan salah satu jenis tanaman tingkat rendah dalam golongan ganggang yang hidup di air laut (Miyashita et al, 2013). Rumput laut bereprodukdi secara generative dan vegetative. Namun ada juga yng dikembang biakan melalui proses kultur jaringan. Rumput laut sudah lazim dikenal dalam dunia perdagangan dan merupakan tumbuhan laut yang bernilai ekonomis penting. Melihat kenyataan tingginya permintaan rumput laut untuk kebutuhan industri dalam negeri maupun untuk memenuhi permintaan terhadap bahan ekspor rumput laut, maka penyediaan bahan baku berkualitas dan berkesinambungan menjadi hal yang sangat penting. Salah satu factor yang mempengruhi keberhasilan budidaya rumput laut ialah metode penanamannya (Pongarrang dkk., 2013). Metode penanaman adalah salah satu faktor yang sangat penting dalam hal melakukan budidaya rumput laut.

Menurut Kordi (2011), ada beberapa metode penanaman yang dikembangkan dalam budidaya rumput laut yang ada di Bali, yaitu metode lepas dasar, metode rakit, metode tali panjang dan metode tali gantung. Sehingga metode penanaman juga dapat mempengaruhi pertumbuhan (Bindu and Levine, 2011). Metode lepas dasar merupakan metode konvensional yang diterapkan di perairan yang berarus. Metode lepas dasar banyak diterapkan di perairan Bali dan sekitarnya. Metode lepas dasar merupakan metode penanaman rumput laut yang memiliki kelemahan yaitu membutuhkan waktu dan biaya yang relative besar, selain itu dalam penggunaan metode ini, masih dapat serangan hama berupa algae yang menempel pada rumput laut seperti ulva $s p$, rumput laut benang (Chaetomorpha crassa) dan hewan predator atau pemangsa seperti ikan baronang (Siganussp.) sehingga mengakibatkan kerugian pada petani rumput laut.

Sebagian besar para petani pembudidaya rumput laut masih banyak yang menerapkan metode penanaman ini. Hal ini dikarenakan metode penanaman tersebut baik dilakukan terkhusus pada spesies rumput laut Eucheuma cottonii.

Rumput laut Eucheuma cottonii (kotoni) merupakan salah satu jenis rumput laut yang memiliki daya resistensi tubuh yang sangat baik dibandingkan dengan jenis rumput laut lainnya
Selain itu adanya serangan ikan terhadap komoditi rumput laut jenis ini sehingga menyebabkan kerugian terhadap petani pembubidaya cukup menjadikan alasan penulis mengangkat rumput laut jenis ini sebagai studi pengamatan.

Permasalahan yang dialami petani rumput laut tersebut merupakan masalah krusial yang memerlukan solusi yang tepat. Salah satu solusi yang bisa dilakukan adalah dengan merancang inovasi baru tentang metode penanaman rumput laut yang efektif dan efisien untuk spesies tertentu. Metode penanaman yang dibutuhkan oleh petani yaitu metode penanaman rumput laut kurung dasar untuk menghindari serangan hama tersebut. Metode budidaya rumput laut yang dimaksud dalam penelitian ini difokuskan pada perbandingan metode budidaya rumput laut Eucheuma cottonii yang telah direkomendasikan oleh Direktorat Jenderal Perikanan, yaitu: metode lepas dasar dengan metode kurung dasar yang nantinya akan dilakukan. Metode lepas dasar merupakan metode penanaman konvensional yang biasa petani rumput laut lakukan sedangkan metode penanaman kurung dasar ialah metode inovasi yang digagas oleh peneliti.

\section{Metode Penelitian}

\subsection{Waktu dan Tempat}

Penelitian ini dilaksanakan pada bulan Februari sampai April 2015 (dengan waktu dua minggu melakukan penelitian pendahuluan dan enam minggu waktu pengamatan). Pengambilan data lapangan yang dilakukan di kawasan Perairan Geger, Bali. Pengambilan data dilakukan seminggu sekali selama enam minggu pengamatan. Data didapatkan dengan cara menimbang pertumbuhan sampel rumput laut kemudian dicatat. Pengambilan data dilakukan secara insitu dimana data kualitas perairan dan data pertumbuhan rumput laut Eucheuma cottonii diambil secara bersama sama pada saat waktu pengumpulan data. Lokasi penelitian dapat dilihat pada Gambar 1.

\subsection{Alat dan Bahan}

Adapun alat-alat yand digunakan dalam penelitian ini dapat dilihat pada Tabel 1 . Sedangkan bibit Eucheuma cottonii seberat 100 gram/bibit adalah bahan yang digunakan dalam penelitian ini. 


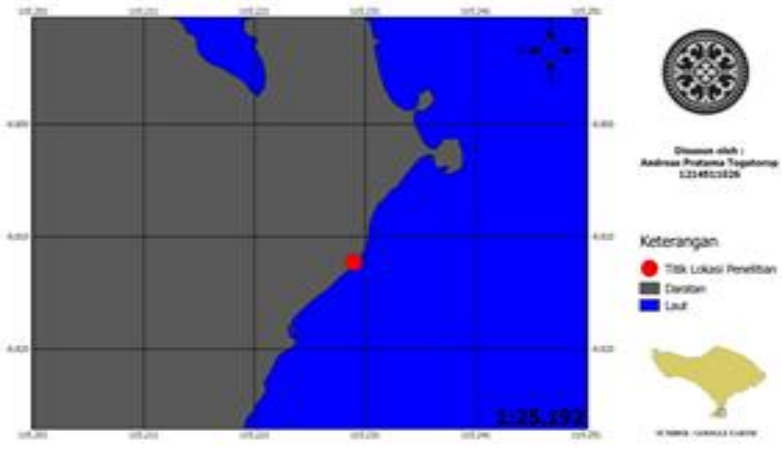

Gambar 1. Peta Lokasi Penelitian

\subsection{Pengambilan Data}

\subsubsection{Data Kualitas Perairan}

Data kualitas perairan diperoleh dari pengukuran langsung di lapangan (in-situ). Pengambilan data dilakukan sebanyak satu kali setiap minggu, dan bersamaan dengan dilakukan sampling pada tanaman rumput laut. Adapun data parameter pendukung perairan antara lain:

a. Kecerahan Perairan

Pengukuran kecerahan perairan dilakukan dengan menggunakan sechhi disk. Secara perlahan - lahan sechi disk dimasukkan dalam air hingga batas kelihatan dan dicatat kedalamannya. Kemudian sechi disk diturunkan sampai tidak kelihatan, kemudian pelan - pelan ditarik sampai nampak lagi dan dicatat kedalamannya. Data yang diperoleh dimasukkan dalam rumus Kecerahan = (Kedalaman 1 - Kedalaman 2) / 2.

b. Kedalaman Perairan

Pengukuran kedalaman perairan dilokasi penelitian dilakukan menggunakan alat Depth Scan.

c. Kecepatan Arus

Perairan Kecepatan arus ditentukan menggunakan current meter. Secara teknis ujung alat ini dimasukkan kedalam air dan langsung mengeluarkan nilai berupa angka yang menunjukkan nilai kecepatan arus di daerah yang diukur.

d. Suhu

Untuk pengkuran suhu perairan dilakukan menggunakan alat Thermometer, yaitu dengan cara mencelupkan kedalam perairan.

e. Oksigen Terlarut (DO) Perairan

Pengukuran dissolved oksigen atau oksigen terlarut $(D O)$ air dilakukan dilapangan dengan menggunakan alat DO Meter.
Tabel 1

Peralatan yang digunakan pada penelitian

\begin{tabular}{|c|c|c|c|}
\hline No & Alat Penelitian & Satuan & Fungsi \\
\hline 1 & $\begin{array}{l}\text { Termometer } \\
\left({ }^{\circ} \mathrm{C}\right)\end{array}$ & ${ }^{\circ} \mathrm{C}$ & $\begin{array}{l}\text { Mengukur suhu } \\
\text { air }\end{array}$ \\
\hline 2 & Secchi disk (m) & $\mathrm{m}$ & $\begin{array}{l}\text { Mengukur } \\
\text { kecerahan air }\end{array}$ \\
\hline 3 & $\begin{array}{l}\text { Hand } \\
\text { Refraktometer }\end{array}$ & $\%$ & $\begin{array}{l}\text { Mengukur } \\
\text { salinitas }\end{array}$ \\
\hline 4 & Cureent Meter & $\mathrm{cm} / \mathrm{s}$ & $\begin{array}{l}\text { Mengukur } \\
\text { kecepatan arus }\end{array}$ \\
\hline 5 & $\mathrm{pH}$ meter & $\mathrm{mg} / \mathrm{l}$ & $\begin{array}{l}\text { Mengukur derajat } \\
\text { keasaman }\end{array}$ \\
\hline 6 & $\begin{array}{l}\text { GPS (Global } \\
\text { Positioning } \\
\text { System) }\end{array}$ & $\begin{array}{l}{ }^{\circ} \mathrm{LS}- \\
{ }^{\circ} \mathrm{BT}\end{array}$ & $\begin{array}{l}\text { Menentukan } \\
\text { posisi penelitian } \\
\text { budidaya rumput } \\
\text { laut }\end{array}$ \\
\hline 7 & Cool Boks & - & $\begin{array}{l}\text { Wadah bibit } \\
\text { rumput laut }\end{array}$ \\
\hline 8 & Perahu & - & Tranportasi \\
\hline 9 & Linggis & - & Memasang patok \\
\hline 10 & Palu & - & $\begin{array}{l}\text { Membuat patok } \\
\text { tertananam } \\
\text { didasar perairan }\end{array}$ \\
\hline 11 & Gunting & - & $\begin{array}{l}\text { Memotong bibit } \\
\text { rumput laut }\end{array}$ \\
\hline 12 & Timbangan & gram & $\begin{array}{l}\text { Menimbang } \\
\text { sampel rumput } \\
\text { laut }\end{array}$ \\
\hline 13 & Kamera & - & Dokumentasi \\
\hline 14 & $\begin{array}{l}\text { Buku dan alat } \\
\text { tulis }\end{array}$ & - & $\begin{array}{l}\text { Mencatat data } \\
\text { yang didapatkan }\end{array}$ \\
\hline 15 & $\begin{array}{l}\text { Tali jalur PE } 4 \\
\text { mm }\end{array}$ & - & $\begin{array}{l}\text { Tali pengikat bibit } \\
\text { rumput laut }\end{array}$ \\
\hline 16 & Tali Rafia & - & $\begin{array}{l}\text { Mengikat bibit } \\
\text { rumput laut }\end{array}$ \\
\hline 17 & Bambu & - & $\begin{array}{l}\text { Sebagai patok } \\
\text { utama penanaman } \\
\text { lepas dasar }\end{array}$ \\
\hline
\end{tabular}

f. Derajat Keasaman $(p H)$ Perairan

Pengukuran derajat keasaman perairan dilakukan menggunakan alat $p H$ Meter. Dimana dalam penggunaannya alat dihidupkan lalu dicelupkan dalam erairan kemudian mencatat hasilnya (berupa angka).

g. Salinitas

Pengukuran kadargaram yang ada diperairan menggunakan alat Refraktometer. Dilakukan dengan cara meneteskan sati tetes air laut pada prisma refraktrometer, kemudian melihat angka yang tertera pada bagian eye piece dan akan ntertera nilai salinitasnya serta mencatat nilai hasil pengamatan. 


\subsubsection{Data Pertumbuhan Rumput Laut}

Data pertumbuhan rumput laut didapatkan dengan cara melakukan sampling pada tanaman rumput laut. Adapun cara untuk menentukan berat pertama bibit berdasarkan pengukuran bibit awal sebesar 100 gram tiap bibit. Sampling pada tanaman rumput laut dilakukan sebanyak enam kali dan akan dilakukan selama \pm 42 hari.

Sampling dilakukan dengan cara menimbang berat bibit mulai dari minggu pertama, minggu kedua dan seterusnya, sampai sampling terakhir dilakukan. Metode yang digunakan dalam penentuan lokasi sampling adalah metode sampling pertimbangan. Metode pengambilan lokasi dan sampel didasarkan atas adanya tujuan tertentu dengan berbagai pertimbangan lalu data pertumbuhan rumput laut akan ditampilkan dalam bentuk tabel.

\subsubsection{Analisa Data Pertumbuhan Rumput Laut}

Data akan dianalisa dengan menggunakan rumus yang terdapat pada persamaan (1), (2), (3) dan persamaan (4) sebagai berikut:

\section{Pertumbuhan}

Penentuan pertumbuhan mutlak dan laju pertumbuhan harian rumput laut diukur pada setiap minggu (sampling) pengamatan $( \pm 42$ hari) dengan menggunakan rumus sebagai berikut :

$$
G=W t-W o
$$

$$
R G R=\frac{W t-W o}{W o} x 100 \%
$$

dimana $G$ adalah pertumbuhan mutlak (gram); $R G R$ adalah relatif grow rate/laju pertumbuhan relatif (\%); Wt adalah berat tanaman pada akhir pemeliharaan (gram); Wo adalah berat tanaman pada awal pemeliharaan (gram); dan $t$ adalah waktu pemeliharaan (hari).

2. Laju Pertumbuhan Harian Spesifik

Penentuan laju pertumbuhan harian spesifik rumput laut yang diukur pada setiap minggu (sampling) pengamatan selama enam minggu ( \pm 42 hari) dengan rumus umum sebagai berikut:

$S G R=\frac{\operatorname{Ln} W t-\operatorname{Ln} W o}{\text { LnWoxt }} \times 100 \%$
3. Rata - rata Pertumbuhan Harian

Rata-rata pertumbuhan harian akan diukur masing-masing perlakuan pada setiap minggu pengamatan (sampling) selama enam minggu ( \pm 42 hari) dengan rumus sebagai berikut :

$A D G=\left(t \sqrt{\frac{w t}{w o}}-1\right) \times 100 \%$

dimana ADG adalah pertumbuhan harian (\%).

Kemudian data pertumbuhan rumput laut dengan metode penanaman kurung dasar dan lepas dasar akan dianalisa dan akan ditampilkan langsung dalam bentuk tabel.

\subsubsection{Analisa Data Uji F}

Uji statistik ini digunakan untuk mengetahui seberapa besar komparasi atau perbedaan antar sampel dari dua metode penanaman yang berbeda. Kemudian dilakukan uji statistik menggunakan SPSS PC + Var 12.0. Prinsip pengujian uji ini adalah melihat perbedaan variasi kedua kelompok data, sehingga sebelum dilakukan pengujian, terlebih dahulu harus diketahui apakah variannya sama (equal variance) atau variannya berbeda (unequal variance). Dalam Test of Homogeneity of variances, jika nilai Sig. lebih besar dari 0,05 (Sig > $0,05)$ menunjukkan bahwa variance data tidak berbeda secara nyata (dengan demikian maka hipotesis H0 ditolak) sehingga memenuhi asumsi berdistribusi normal dan memenuhi syarat untuk penggunaan analisis varians.

Kemudian data dinyatakan memiliki pengaruh yang nyata bila F.Hitung > F.Tabel, dan data dinyatakan tidak sama berpengaruh nyata bila F.Hitung < F.Tabel. Data pertumbuhan rumput laut Eucheuma cottonii hasil pengamatan selanjutnya akan dianalisis dan ditampilkan dalam tabel sidik ragam ANOVA.

\section{Hasil dan Pembahasan}

\subsection{Pertumbuhan}

\subsubsection{Pertumbuhan Mutlak}

Berdasarkan Gambar 2 dapat dilihat bahwa pada minggu pertama merupakan nilai yang menghasilkan pertumbuhan mutlak yang paling baik dari perhitungan selama enam minggu pengamatan. Dimana tercatat sampel memiliki nilai pertumbuhan sebesar 11,20 gram untuk 
metode tanam kurung dasar dan $-31,40$ gram untuk metode penanaman lepas dasar. Semakin kecil bobot awal yang digunakan maka pertumbuhan mutlak rumput laut semakin besar. Hal ini dikarenakan pada bobot awal yang lebih kecil bagian ujung-ujung pada cabang thallus pada tanaman uji rumput laut Eucheuma cottonii mengalami pertumbuhan yang lebih cepat dibandingkan dengan bobot awal lainnya. Pada bobot awal yang kecil, ujung-ujung pada cabang thallus mendapatkan makanan yang cukup memadai dari nutrisi yang terkandung dalam air. Selain itu dikarenakan juga pergerakan air dan asupan sinar matahari yang cukup baik untuk fotosintesis sehingga rumput laut mengalami pertumbuhan yang optimal.

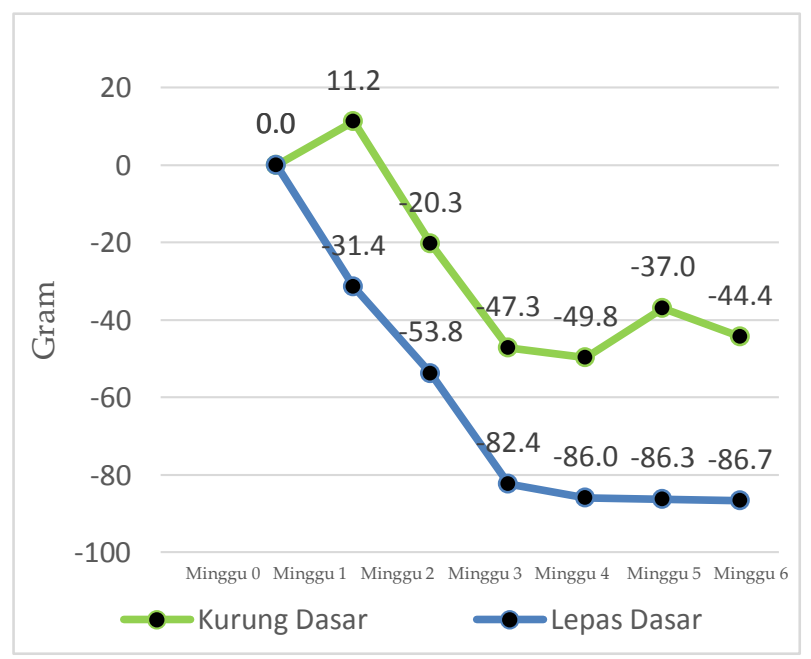

Gambar 2. Grafik data pertumbuhan mutlak

Faktor lingkungan yang baik akan meningkatkan pertumbuhan sedangkan faktor lingkungan yang tidak baik menyebabkan pertumbuhan yang tidak optimal. Pada metode penanaman kurung dasar resiko terhadap serangan ikan predator tidak sebesar yang oleh rumput laut yang berada pada teknik penanaman lepas dasar. Hal ini terlihat dari data yang menunjukkan berat rata - rata pertumbuhan mutlak yang terus mengalami penurunan yang terjadi pada setiap minggunya terkhusus pada metode penanaman lepas dasar. Tercatat dari data awal sebesar 100 gram terus mengalami penurunan. Untuk minggu pertama sebesar $-31,40$ gram, minggu kedua turun menjadi $-53,80$ gram, minggu ketiga kembali mengalami penurunan menjadi $-82,40$ gram, minggu keempat masih mengalami penurunan menjadi $-86,00$ gram. Namun minggu kelima tidak terjadi penurunan berat pertumbuhan, dari data tercatat sebesar 86,30 gram artinya hanya sedikit perubahan dari minggu sebelumnya. Dan kembali pada pengamatan minggu terakhir berat pertumbuhan mutlak kembali mengalami penurunan sebesar 86,70 gram. Kemudian faktor yang menyebabkan berkurangnya pertumbuhan relative/nisbi adalah serangan penyakit ice - ice yang menterang bagian thallus pada tubuh rumput laut. Pada saat rumput laut terserang gejala penyakit ice-ice bobot bibit akan kecenderungan berkurang karena disebabkan penyebaran penyakit ice - ice yang merusak cabang-cabang thallus pada rumpun rumput laut.

Penyebab gejala terjadinya penyakit ice-ice dapat dipengaruhi oleh berkembangnya rumput laut jenis lain yang menempel atau epifit. Hal ini dapat diidentifikasikan sebagai faktor utama yang menyebabkan berkembangnya ice-ice dan terdapat hubungan yang terkait diantaranya dan penyebab lain adanya tanaman epifit. Terlihat dari populasi yang besar dari bakteri ditemukan pada jaringan yang terkena ice-ice, tetapi menyimpulkan bahwa sebenarnya timbulnya bakteri itu merupakan serangan sekunder. Kemungkinan efektivitas serangan bakteri itu terjadi pada saat pertumbuhan tanaman tidak efektif.

Laju fotosintesis dan respirasi rumput laut Eucheuma cottonii dipengaruhi oleh temperatur. Fisiologis ditemukan maksimum pada fotosintesis pada $25^{\circ} \mathrm{C}$ dan mengamati bahwa respirasi bertambah sebesar $50-60 \%$ dari suhu $15^{\circ} \mathrm{C}$ ke $20^{\circ} \mathrm{C}$. Autooksidasi meningkat tajam dari dari $25^{\circ} \mathrm{C}$ sampai $40^{\circ} \mathrm{C}$. Ketika thallus telah dikembalikan ke standar $25^{\circ} \mathrm{C}$ setelah maksimal ditoleransi nilainilai itu sebelumnya diperoleh tidak diulangi secara konsisten. Hal ini ditafsirkan sebagai bukti bahwa jaringan rusak pada temperatur tinggi.

\subsubsection{Laju Pertumbuhan Relatif}

Pertumbuhan rumput laut Eucheuma cottonii pada minggu pertama untuk masing-masing metode tanam menunjukkan perbedaan yang signifikan (Gambar 3). Dimana rata - rata laju pertumbuhan relatif pada metode tanam yang pertama bernilai $11,20 \%$ dan pada metode penanaman kedua memiliki nilai $-31,40 \%$. Pada minggu pertama ini tanaman budidaya rumput laut mengalami fase lag atau adaptasi. Pada fase ini tanaman rumput laut masih berada dalam masa adaptasi dengan lingkungan Perairan Geger. 
Rata - rata laju pertumbuhan relatif pada minggu kedua mengalami penurunan. Dimana didapati nilai penurunan $-20,30 \%$ dan $-53,80 \%$ pada masing - masing metode penanaman. Hal ini dikarenakan rumput laut berada dalam masa pertumbuhan awal setelah masa adaptasi karena baru ditanam dari potongan-potongan thallus baru. Menurut Aquilino et al. (2009) menyatakan bahwa proses adaptasi rumput laut menghambat laju pertumbuhannya karena sebagian energi digunakan untuk tetap bertahan hidup karena adanya pengurangan energi yang masuk dan meningkatnya energi yang keluar sehingga laju pertumbuhan mengalami penurunan. Hal ini sesuai dengan pernyataan Nishihara et al. (2013) bahwa pengurangan energi pada rumput laut diduga terjadi karena perubahan kebiasaan fisiologisnya. Laju pertumbuhan menunjukkan kemampuan fisiologis rumput laut untuk beradaptasi dengan lingkungan.

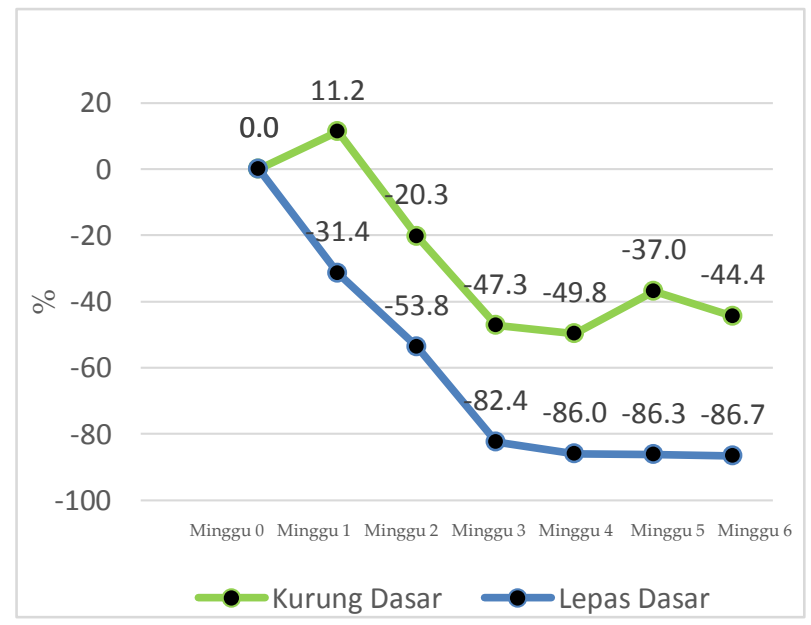

Gambar 3. Grafik data Laju Pertumbuhan Relatif (\%)

Pada minggu ketiga kembali laju pertumbuhan relatif rumput laut mengalami penurunan, bahkan terkhusus untuk metode penanaman lepas dasar pada minggu ketiga rata - rata penurunan laju pertumbuhan harian mengalami penurunan laju pertumbuhan terbesar dari enam minggu hasil pengamatan. Untuk metode penanaman yang pertama menghasilkan data sebesar $-47,30 \%$ dan untuk metode penanaman kedua menghasilkan data sebesar $-82,40 \%$. Selain itu penurunan laju pertumbuhan pada minggu ketiga diduga karena kondisi lingkungan perairan budidaya rumput laut Eucheuma cottonii yang kurang baik, sehingga menyebabkan pertumbuhan yang tidak optimal. Dan serangan hewan pemangsa berupa ikan baronang merupakan faktor terbesar penyebab terhambatnya laju pertumbuhan rumput laut di perairan Geger. Mok et al. (2012) menyatakan parameter kualitas perairan berperan penting dalam budidaya rumput laut, yaitu dalam menentukan laju pertumbuhan dan adaptasi rumput laut. Hasil pengukuran faktor fisik pada minggu ketiga didapatkan bahwa kecepatan arus yang lebih rendah senilai $10 \mathrm{~cm} / \mathrm{s}$ dibandingkan hasil pengukuran pada minggu sebelumnya. Kecepatan arus yang rendah ini menyebabkan kurangnya daya untuk membersihkan sedimen atau lumpur yang terlarut dalam air yang menutupi permukaan thallus.

Besarnya kecepatan arus yang ideal berkisar antara $20-40 \mathrm{~cm} /$ detik. Akan tetapi adanya pergerakan air yang menyebabkan terangkatnya sedimen yang berada didasar perairan naik dan menutupi permukaan thallus menyebabkan laju pertumbuhan menjadi terhambat. Besarnya kecepatan arus sangat penting karena membantu membersihkan lumpur yang menempel pada permukaan thallus oleh sedimen atau lumpur yang menempel tersebut menyebabkan terhalangnya sinar matahari dan nutrien untuk sampai ke bagian thallus (Xia et al., 2012; Yong et al., 2013). Lumpur yang menempel pada permukaan thallus rumput laut akan menghambat laju pertumbuhannya. Thallus yang tertutup oleh lumpur yang menempel tersebut menyebabkan terhalangnya sinar matahari dan nutrien untuk sampai ke bagian thallus sehingga menghalangi proses fotosintesis. Keadaan ini menyebabkan laju pertumbuhan rumput laut terhambat.

Laju pertumbuhan pada minggu keempat kembali mengalami kenaikan, sehingga laju pertumbuhannya mulai membaik dari minggu sebelumnya. Pada minggu keempat ini tanaman budidaya rumput laut mengalami fase logaritmik. Pada fase logaritmik ini tanaman mengalami pertambahan ukuran secara eksponensial sejalan dengan waktu. Hal ini didukung hasil pengukuran analisis kecerahan perairan yang sangat baik pada minggu ini. Semakin baik kondisi kecerahan pada suatu perairan maka semakin banyak juga cahaya yang masuk keperairan yang nantinya dapat berperan pada proses fotosintesis yang dialami oleh rumput laut. Pada minggu keempatrata - rata laju pertumbuhan relatif rumput laut Eucheuma cottonii mengalami sedikit kenaikan, tercatat sebesar $-49,80 \%$ pada metode penanaman kurung dasar dan $-86,00 \%$ pada metode penanaman lepas dasar. 
Pada minggu kelima laju pertumbuhan harian rumput laut Eucheuma cottonii mengalami kenaikan, tercatat sebesar $-37,00 \%$ pada metode penanaman pertama dan $-86,30$ pada metode penanaman kedua yang mengalami penurunan.Tanaman uji rumput laut Eucheuma cottonii berada pada fase linier. Pada fase linier terjadi pertumbuhan secara konstan, biasanya pada laju maksimum selama beberapa waktu lamanya. Sedangkan pada minggu keenam laju pertumbuhan mengalami penurunan. Tanaman uji rumput laut Eucheuma cottonii berada pada fase penuaan. Pada fase ini terjadi pada saat tumbuhan sudah mencapai kematangan dan mulai menua. Untuk metode penanaman pertama didapatkan sebesar $-44,40 \%$ dan metode penanaman kedua didapatkan hasil sebesar $-86,70 \%$.

Pada minggu pertama sampai terjadi adanya sedikit peningkatan laju pertumbuhan sehingga dapat dikatakan pertumbuhannya stabil. Hal ini diduga disebabkan pada bobot awal 100 gr/rumpun pada penanaman bibit pada setiap rumpun, thallus hanya mengalami sedikit luka akibat pemotongan pada jaringan tanaman Eucheuma cottonii. Menurut Dwijoseputro (1983) menyatakan bahwa jika suatu jaringan itu terluka, maka CO2 akan lebih banyak terlepas. Di sekitar bidang luka itu akan lebih banyak gula sehingga respirasi bertambah giat sebagai manifestasi dari aktivitas sel-sel parenkim yang menutup luka tersebut.

Tanaman Eucheuma cottonii dapat tumbuh baik dengan bantuan gerakan air. Dalam budidaya rumput laut arus perairan sangat berperan penting (Olanrewaju, et al., 2016; Komatsu et al., 2014). Efek gerakan air berpengaruh terhadap bahan nutrien pada pertumbuhan. Gerakan air membantu tumbuhan menjadi bersih dari menempelnya substrat lumpur dan biota, dan membawa bahan nutrien Satu faktor penting mengenai efek gerakan air adalah lapisan batas yang tidak bercampur. Lapisan batas yang tidak bercampur disebabkan oleh friksi antar thallus yang melingkupi perairan. Ketebalan lapisan ini berbanding terbalik dengan pergerakan air dan pergolakan aliran yang mengganggu batas lapisan itu Neish, (2003).

\subsubsection{Laju Pertumbuhan Harian Spesifik}

Berdasarkan Gambar 4 dapat dilihat bahwa persentase rata - rata pertumbuhan laju pertumbuhan harian spesifik tertinggi pada minggu pertama sebesar 0,33 \%/7 hari untuk metode penanaman kurung dasar dan $1.19 \% / 7 h a r i$ pada metode penanaman lepas dasar. Sedangkan pada minggu kedua persentase persentase rata - rata pertumbuhan harian spesifk mengalami penurunan, masing - masing sebesar 0,40 \%/14 hari dan -1,31 \%/14 hari pada setiap metode penanaman. Kemudian didapatkan pada minggu ketiga kembali mengalami penurunan masing - masing $-0,80 \% / 21$ hari dan $-1,93 \% / 21$ hari pada masing - masing metode penanaman. Kembali pada minggu keempat mengalami penurunan persentaserata - rata laju pertumbuhan harian spesifik,masing - masing -0,62 \%/28 hari dan -1,62 \%/28 hari pada kedua metode penanaman. Namun pada minggu kelima untuk terjadi kenaikan persentase pada kedua metode penanaman. Masing - masing menjadi -0.35 \%/35 hari untuk metode penanaman kurung dasar 1,33\%/35 hari pada metode lepas dasar. Namun pada minggu keenam kembali mengalami kenaikan persentase pertumbuhan harian spesifik. Masing masing sebesar -0,34 \%/42 hari dan $1,11 \% / 42$ hari pada masing - masing metode penanaman. Pergerakan air mempengaruhi kecepatan tumbuh rumput laut dan arus merupakan bentuk gerakan air yang lebih baik karena dapat mempercepat pertumbuhan rumput laut. Namun kembali faktor penghambat pertumbuhan berupa serangan hewan pemangsa dan predator menjadi faktor utama yang menyebabkan menurunnya persentase pertambahan berat yang dialami oleh rumput laut baik yang ditananam didalam kontruksi kurung dasar dan lepas dasar.

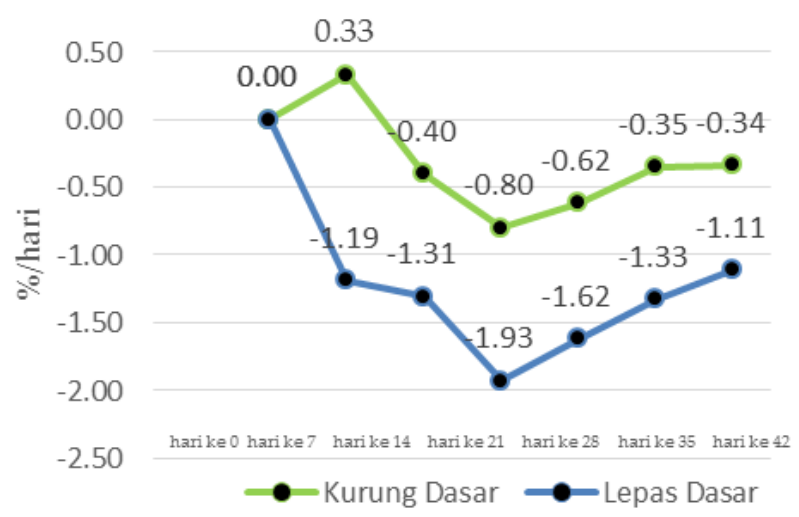

Gambar 4. Grafik data laju pertumbuhan relatif

Pertumbuhan rumput laut tidak hanya dikendalikan oleh perubahan satu faktor saja, 
tetapi semua parameter lingkungan akan berpengaruh secara bersama. Proses fotosintesis rumput laut dipengaruhi oleh intensitas cahaya, temperatur dan jumlah gas karbondioksida dalam perairan serta kepadatan thallus atau bobot awal yang digunakan pada saat penanaman. Malina dkk. (2014) menyatakan bahwa variasi secara umum dalam produktivitas rumput laut telah diamati pada awal pengembangan budidaya tanaman Eucheuma cottonii. tapi gejala ini belum dipahami dengan baik. Hal ini diarahkan pada efek panen berhubungan dengan faktor oseanografi, seperti arah angin, pergerakan air, ketersediaan unsur hara dan perubahan temperatur. Sedangkan gejala sekunder meliputi aktivitas hama dan penyakit.

\subsubsection{Pertumbuhan Harian}

Berdasarkan hasil analisa, rata - rata pertumbuhan harian rumput laut pada sampling pertama (7 hari) menunjukkan bahwa rata-rata hasil pertumbuhan harian sangat jauh berbeda, yaitu pada rumput laut metode penanaman kurung dasar persentase rata - rata pertumbuhan harian yaitu $1,41 \%$, sedangkan pada rumput laut metode penanaman lepas dasar yaitu $-16,4 \%$ (Gambar 5).

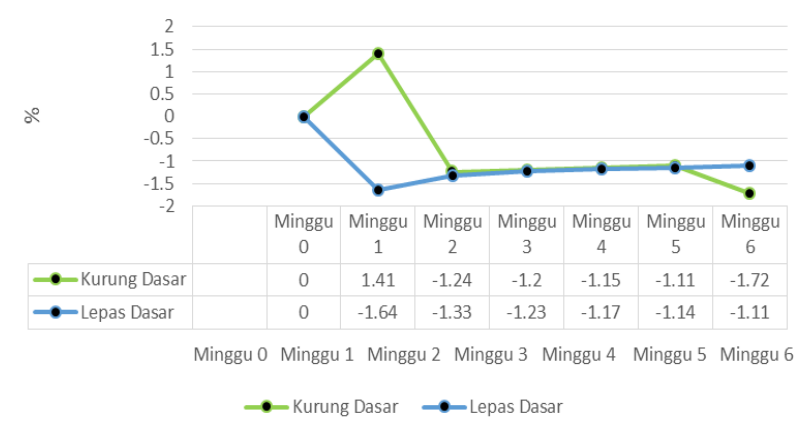

Gambar 5. Grafik data pertumbuhan harian

Pada sampling kedua (14 hari) persentase rata rata pertumbuhan harian pada metode penanaman kurung dasarterlihat hampir sama seperti persentase rata - rata pertumbuhan harian rumput laut untuk metode penanaman lepas dasar, yaitu masing masing sebesar $-1,24 \%$, dan $-1,33 \%$. Pada persentase rata - rata pertumbuhan harian metode penanaman rumput laut terjadi penurunan untuk metode penanaman kurung dasar sedangkan untuk metode penanaman lepas dasar mengalami kenaikan persentase rata - rata pertumbuhan harian.
Pada sampling ketiga (21 hari) persentase rata rata pertumbuhan harian pada metode penanaman kurung dasarterlihat lebih tinggi sedikit dibanding persentase rata - rata pertumbuhan harian rumput laut pada metode penanaman lepas dasar, yaitu persentase pertumbuhan harian untuk masing masing metode penanaman sebesar $-1,2 \%$ dan $1,23 \%$. Pada kedua metode penanaman terjadi kenaikan persentase pertumbuhan harian dibanding pada sampling 14 hari pasca penanaman, dimana persentase rata - rata pertumbuhan harian rumput laut metode penanaman kurung dasar naik dari $-1,24 \%$ hingga $-1,20 \%$, sedangkan penurunan pertumbuhan rumput laut metode penanaman lepas dasar dari $1,33 \%$ naik hingga $1,23 \%$.

Pengukuran sampling keempat (28 hari) persentase rata - rata pertumbuhan harian pada metode penanaman kurung dasarterlihat lebih tinggi sedikit dibanding persentase rata - rata pertumbuhan harian rumput laut metode penanaman lepas dasar, yaitu persentase rata - rata pertumbuhan harian untuk masing - masing metode penanaman sebesar $-1,15 \%$ dan $-1,17 \%$. Dari kedua metode penanaman terjadi persentase kenaikan pertumbuhan harian dibandingkan dengan sampling ketiga (21 hari) yaitu pada rumput laut metode kurung dasar dari $-1,2 \%$ naik hingga mencapai $-1,15 \%$, sedangkan pada metode lepas dasar dari -1,23\% naik hingga mencapai $1,17 \%$.

Pada sampling kelima (35 hari) persentase rata - rata pertumbuhan harian pada metode penanaman kurung dasarterlihat hampir sama seperti persentase rata - rata pertumbuhan harian rumput laut untuk metode penanaman lepas dasar, yaitu masing masing sebesar $-1,11 \%$, dan $1,14 \%$. Pada persentase rata - rata pertumbuhan harian metode penanaman rumput laut terjadi penurunan untuk metode penanaman kurung dasar sedangkan untuk metode penanaman lepas dasar mengalami kenaikan persentase rata - rata pertumbuhan harian.

Pada sampling keenam (42 hari) persentase rata - rata pertumbuhan harian pada metode penanaman kurung dasarterlihat lebih rendah dibanding persentase rata - rata pertumbuhan harian rumput laut pada metode penanaman lepas dasar, yaitu persentase pertumbuhan harian untuk masing - masing metode penanaman sebesar -1,72 $\%$ dan $-1,11 \%$. Untuk metode penanaman kurung dasar terjadi penurunan persentase pertumbuhan 
harian berbanding terbalik dengan rumpur laut yang ditanaman melalui metode penanaman lepas dasar yang mengalami kenaikan rata - rata pertumbuhan harian. Dimana persentase rata rata pertumbuhan harian rumput laut metode penanaman kurung dasar turun dari $-1,11 \%$ menjadi $-1,72 \%$, sedangkan penurunan pertumbuhan rumput laut metode penanaman lepas dasar dari $-1,14 \%$ naik hingga $-1,11 \%$.

\subsection{Data Pertumbuhan dan Analisis Uji F}

\subsubsection{Data Pertumbuhan Rumput Laut}

Berat pertumbuhan rumput laut Eucheuma cottoni pada minggu pertama untuk masing - masing metode penanaman menunjukkan pertumbuhan yang berbeda. Untuk metode penanaman kurung dasar didapatkan pertambahan berat sampel sebesar 111,2 gram dari berat rata - rata awal sebesar 100 gram dan untuk metode penanaman lepas dasar didapatkan penurunan berat sampel sebesar 68,6 gram dari berat rata - rata awal sebesar 100 gram (Gambar 6). Hal ini menjelaskan bahwa pada penanaman rumput laut di minggu pertama masih mengalami fase lag atau adaptasi dengan lingkungan Perairan Geger, Bali.

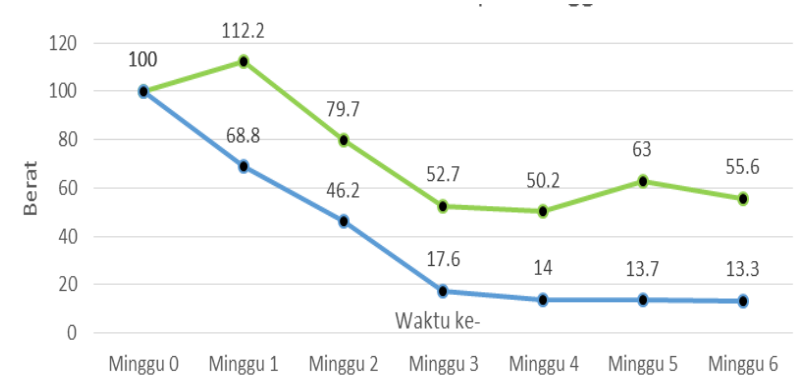

\section{- Kurung Dasar - -Lepas Dasar}

Gambar 6. Grafik pertambahan berat pertumbuhan harian

Berat pertumbuhan rumput laut Eucheuma cottoni pada minggu kedua dari kedua metode penanaman sama - sama mengalami penurunan berat. Untuk penanaman menggunakan metode kurung dasar mengalami penurunan berat yang sangat drastis, dari berat keseluruhan sebesar 111,2 gram berkurang menjadi 79,9 gram. Sedangkan untuk metode lepas dasar dari berat 68,6 berkurang menjadi 46,2 gram. Hal ini dikarenakan adanya gangguan dari lingkungan perairan berupa serangan ikan pemangsa.
Sementara untuk berat minggu ketiga didapatkan data berat rumput laut pada metode penanaman kurung dasar kembali mengalami penurunan berat. Berat rata - rata yang didapat sebesar 52,7 gram, sedangkan untuk penanaman lepas dasar memiliki berat rata - rata sebesar 17,6 gram. Dari data yang didapatkan kembali mengindikasikan bahwa serangan ikan pemangsa rumput laut masih menjadi faktor penghambat pertumbuhan rumput laut.

Untuk pengukuran berat rata - rata rumput laut pada minggu keempat didapatkan data dari penanaman kurung dasar sebesar 50,2 gram dan untuk penanaman lepas dasar didapatkan berat rata - rata keseluruhan sebesar 14 gram.

Terdapat perbedaan berat rata - rata keseluruhan pada pengukuran minggu kelima, untuk penanaman dengan metode kurung dasar mengalami pertambahan berat dari berat rata rata 50,2 gram menjadi 63 gram. Sementara untuk metode penanaman lepas dasar kembali mengalami penurunan berat. Dari berat rata- rata keseluruhan 14 gram menjadi 13,7 gram.

Pada minggu keenam kembali berat rumput laut tetap mengalami penurunan. Untuk metode penanaman kurung dasar berat rumput laut memiliki berat rata rata sebesar 55,6 gram dan untuk metode penanaman lepas dasar berat rata rata keseluruhan sebesar 13,3 gram.

\subsubsection{Analisis Uji F Selisih Pertumbuhan Rumput Laut}

Analisis data Uji F terhadap data selisih pertumbuhan Rumput laut Eucheuma cottonii menunjukan bahwa data selisih pertumbuhan didapatkan dari data rata - rata seminggu setelah penanaman dikurangkan dengan data rata - rata awal rumput laut ditanaman. Kemudian untuk data selanjutnya didapatkan dari selisih data seminggu setelah penanaman dikurang dengan data seminggu sebelumnya. Proses pengambilan data didapatkan secara terus menerus sampai rumput laut berumur 42 hari (6 minggu). Hasil pengujian statistik menggunakan analisis uji Fmenunjukkan bahwa nilai sig $<0,05$ yang didapatkan dari nilai sinifikasi sebesar 0,476 >0,05 pada taraf kepercayaan $5 \%$ (Tabel 2). Maka $\mathrm{H}_{0}=$ diterima dan $\mathrm{H}_{1}=$ diolak, dapat disimpulkan tidak terdapat perbedaan secara nyata sehingga dapat disimpulkan tidak adanya perbedaan yang nyata antara pertumbuhan rumput laut Eucheuma cottonii 
dengan menggunakan metode tanam kurung dasar dan metode tanam lepas dasar terhadap pertumbuhan rumput laut.

Tabel 2

Analisis uji F pada tabel sidik ragam ANOVA

\begin{tabular}{llllll}
\hline Keterangan & $\begin{array}{c}\text { Sum of } \\
\text { Squares }\end{array}$ & df & $\begin{array}{c}\text { Mean } \\
\text { Square }\end{array}$ & F & Sig. \\
\hline $\begin{array}{l}\text { Between } \\
\text { Groups }\end{array}$ & 156.241 & 1 & 156.241 & .549 & .476 \\
Within & 2847.088 & 10 & 284.709 & & \\
$\begin{array}{l}\text { Groups } \\
\text { Total }\end{array}$ & 3003.329 & 11 & & & \\
\hline
\end{tabular}

Dari tabel sidik ragam ANOVA tercatat nilai $\mathrm{F}$ hitung (F) tercatat memiliki nilai sebesar 0.549 dan memiliki nilai yang lebih kecil dari $\mathrm{F}$ tabel 5\% yaitu sebesar (4.10), maka kembali dapat disimpulkan penggunaan metode penanaman dengan menggunakan metode lepas dasar tidak berpengaruh secara nyata terhadap pertumbuhan rumput laut Eucheuma cottonii pada taraf 5\%.

Pasca setelah penanaman, bibit rumput laut yang ditanam harus selalu di kontrol dan dipelihara dengan baik melalui pengawasan yang teratur. Selama penelitian ditemukan adanya biota penempel pada rumput laut Eucheuma cottonii berupa sedimen yang terangkat dari dasar dan terbawa arus perairan. Untuk mengatasi hal ini dilakukan upaya pembersihan thallus dari biota yang menempel karena menutupi sebagian thallus rumput laut supaya tidak mengganggu pertumbuhan perairan.

Pembersihan tanaman budidaya rumput laut dengan cara menggoyangkan atau membersihkan lumpur yang melekat pada Eucheuma cottonii selain itu dilakukan juga pembersihan tali tanam dan menguatkan tali ikatan tanam. Tujuannya agar kotoran dapat terlepas; rumput laut terbebas dari tanaman epifit karena dapat menghambat proses fotosintesis yang berhubungan dengan pertumbuhan. Selain itu juga untuk mengetahui pertumbuhannya maka dilakukan kegiatan sampling yang rutin dilakukan setiap minggunya.

Hasil penelitian terhadap parameter perairan menunjukkan kualitas perairan yang tidak stabil, walaupun dengan kondisi lingkungan tersebut tanaman budidaya rumput laut Eucheuma cottonii masih dapat tumbuh tetapi pertumbuhannya kurang maksimal. Pertumbuhan rumput laut diduga tidak hanya dipengaruhi oleh satu faktor saja, tetapi semua parameter lingkungan akan berpengaruh secara bersama-sama (Utojo dkk., 2007) termasuk juga penempatan kontruksi penanam perlu diperhatikan. Terlihat pada lokasi penananam masih dipengaruhi oleh adanya ombak, sehingga rumput laut masih mendapatkan asupan nutrient yang dibawa oleh air dan juga faktor kedalaman yang nantinya mempengaruhi kondisi pertumbuhaan rumput laut dari jangkauan oleh sinar matahari (Susilowati et al., 2012). Arus yang terukur dari hasil pengamatan selama penelitian berkisar antara $0,1 \mathrm{~m} / \mathrm{s}-0,2 \mathrm{~m} / \mathrm{s}$. Sementara besarnya kecepatan arus yang ideal berkisar antara $20-40 \mathrm{~cm} /$ detik. Besarnya kecepatan arus sangat penting karena membantu membersihkan lumpur yang menempel pada permukaan thallus oleh sedimen atau lumpur yang menempel tersebut menyebabkan terhalangnya sinar matahari dan nutrien untuk sampai ke bagian thallus sehingga kandungan karagianan yang ada pada rumput laut juga terjaga baik (Basmal dkk., 2009).

Selain itu adanya gangguan eksternal berupa serangan hewan pemangsa merupakan faktor utama yang menyebabkan terhambatnya pertumbuhan pada rumput laut. Dapat dibuktikan dari sampel kedua metode penanaman rumput laut yang berbeda. Terlihat jelas pada metode penanaman kurung dasar menhasilkan bobot dan pertumbuhannya dapat dikatakan lebih baik dibandingkan dengan bobot dan pertumbuhan rumput laut yang ada pada penanaman konvensional yang dilakukan oleh petani.

Kelemahan metode penanaman kurung dasar terletak pada biaya yang relatif mahal untuk membuatnya, biaya tambahan tersebut didapatkan dari penggunaan alat tambahan seperti jaring sehingga dapatmemberatkan nelayan, karena biasanya mereka menggunakan barang - barang yang mudah dan murah. Dengan penggunaan jaring pada kontruksi penanaman diharapkan mampu meminimalisir penurunan produksi rumput laut dari adanya serangan ikan predator. Penanaman dengan metode lepas dasar sebelumnya sudah pernah dilakukan di daerah Perairan Kalianda oleh Wijayanto dkk. (2011) dan oleh Selvavinayagam and Dharmar (2016) di perairan pantai tenggara India.

Tercatat pertumbuhan rumput laut Eucheuma cottoni menghasilkan pertumbuhan yang positif. 
Hal ini berbanding terbalik dengan hasil yang didapatkan pada penelitian kali ini yang menhasilkan pertumbuhan rumput laut yang negatif.

Hal ini dikarenakan di daerah perairan di Kalianda (Lampung Selatan) memiliki karakteristik ombak yang relatif tenang. Selain itu lokasi penanaman yang terletak di muara sungai juga menjadi salah satu faktor keberhasilan pertumbuhan karena masih adanya pengaruh masukan nutrient yang berasal dari daratan. Dalam proses penanaman rumput laut pada penelitian ini, kondisi ekologis perairan masih didalam batas kisaran kelayakan yang normal dalam hal melakukan penanaman rumput laut jenis Eucheuma cottonii.

\section{Simpulan}

Metode penanaman kurung dasar tidak memberikan perbedaan secara nyata dari metode penanaman lepas dasar dengan nilai sinifikasi sebesar 0.476 pada taraf kepercayaan sebesar $5 \%$. Selain itu penggunaan metode penanaman kurung dasar ini juga masih belum terlalu efektif untuk diaplikasikan pada proses pembudidayaan rumput laut Eucheuma cottoni di Perairan Geger.

\section{Ucapan terimakasih}

Penulis mengucapkan terima kasih kepada seluruh pihak yang telah memberikan masukandan bimbingan dalam pembuatan jurnal ilmiah ini. Terimakasih yang sebesar - besarnya kepada Fakultas Kelautan dan Perikanan atas fasilitas yang telah diberikan. Kepada rekan - rekan dalam pengambian data dan penulis juga mengucapkan terimakasih kepada seluruh pihak yang sudah memberikan doa dan dukungannya.

\section{Daftar Pustaka}

Aquilino, K. M., Bracken, M. E., Faubel, M. N., \& Stachowicz, J. J. (2009). Local - scale nutrient regeneration facilitates seaweed growth on wave exposed rocky shores in an upwelling system. Limnology and Oceanography, 54(1), 309-317.

Basmal, J., Utomo, B. S. B., dan Sedayu, B. B. (2009). Mutu Semi Refined Carraeenan (SCR) Yang Didaur Ulang. Jurnal Pasca Panen dan Bioteknologi Kelautan dan Perikanan. Vol 4. ,1-11.

Bindu, M. S., \& Levine, I. A. (2011). The commercial red seaweed Kappaphycus alvarezii-an overview on farming and environment. Journal of Applied Phycology, 23(4), 789-796.

Komatsu, T., Mizuno, S., Natheer, A., Kantachumpoo, A., Tanaka, K., Morimoto, A., Hsiao S. T., Rothäusler E. A., Shishidou H., Aoki, M., \& Ajisaka, T. (2014). Unusual distribution of floating seaweeds in the East China Sea in the early spring of 2012. Journal of applied phycology, 26(2), 1169-1179.

Kordi, K. M. G. H. (2011). Kiat Sukses Budidaya Rumput Laut di Laut dan Tambak. Yogyakarta, Indonesia: Andi

Miyashita, K., Mikami, N., \& Hosokawa, M. (2013). Chemical and nutritional characteristics of brown seaweed lipids: A review. Journal of Functional Foods, 5(4), 1507-1517.

Mok, W. J., Senoo, S., Itoh, T., Tsukamasa, Y., Kawasaki, K. I., \& Ando, M. (2012). Assessment of concentrations of toxic elements in aquaculture food products in Malaysia. Food Chemistry, 133(4), 13261332.

Nishihara, G. N., Noro, T., \& Terada, R. (2013). Effect of temperature and light on the photosynthesis as measured by chlorophyll fluorescence of cultured Eucheuma denticulatum and Kappaphycus sp.(Sumba strain) from Indonesia. Journal of applied phycology, 25(2), 399-406.

Olanrewaju, S. O., Magee, A., Kader, A. S. A., \& Tee, K. F. (2016). Simulation of offshore aquaculture system for macro algae (seaweed) oceanic farming. Ships and Offshore Structures, 1-10. DOI: http://dx.doi.org/ $\underline{10.1080 / 17445302.2016 .1186861}$

Pongarrang, D., Rahman, A., \& Iba, W. (2013). Pengaruh Jarak Tanam dan Bobot Bibit Terhadap Pertumbuhan Rumput Laut (Kappaphycus alvarezii) Menggunakan Metode Vertikultur. Jurnal Mina Laut Indonesia, 3(12), 94-112.

Selvavinayagam, K. T., \& Dharmar, K. (2016). Selection of potential method for cultivation and seed stock maintenance of Kappaphycus alvarezii during the northeast monsoon in southeast coast of India. Journal of Applied Phycology, 1-12. DOI: http://dx.doi.org/ 10.1007/s10811-016-0967-4.

Susilowati, T., Rejeki, S., Dewi, E. N., \& Zulfitriani. (2012). Pengaruh Kedalaman Terhadap Pertumbuhan Rumput Laut (Eucheuma cottonii) yang Dibudidayakan Dengan Metode Longline di Pantai Mlonggo, Kabupaten Jepara. Jurnal Saintek Perikanan Vol. 8, no. 1 .

Malina., A. C., Tassakka, A. R., Latama, G., \& Rustam, R. (2014). Pengaruh Perbedaan Varietas Rumput Laut (Kappaphycus sp) dan Variasi Kedalaman Terhadap Pertumbuhan dan Produksi Rumput Laut Menggunakan Metode Budidaya “Top Down”. Jurnal Ilmu Kelautan dan Perikanan. Vol 24, no 1.

Utojo, U., Mansyur, A., Pantjara, B., Pirzan, A. M., \& Hasnawi, H. (2007). Kondisi lingkungan perairan 
Teluk Mallasoro yang layak untuk lokasi pengembangan budi daya rumput laut (Eucheuma sp.). Jurnal Riset Akuakultur, 2(2), 243-255.

Wijayanto, T., Hendri, M., \& Aryawati, R. (2011) Studi Pertumbuhan Rumput Laut Eucheuma cottonii dengan Berbagai Metode Penanaman yang berbeda di Perairan Kalianda, Lampung Selatan. Maspari Journal 3(2), 51-57.
Xia, S., Yang, H., Li, Y., Liu, S., Zhou, Y., \& Zhang, L. (2012). Effects of different seaweed diets on growth, digestibility, and ammonia-nitrogen production of the sea cucumber Apostichopus japonicus (Selenka). Aquaculture, 338, 304-308.

Yong, Y. S., Yong, W. T. L., \& Anton, A. (2013). Analysis of formulae for determination of seaweed growth rate. Journal of applied phycology, 25(6), 1831-1834.

(C) 2017 by the authors; licensee Udayana University, Indonesia. This article is an open access article distributed under the terms and conditions of the Creative Commons Attribution license (http://creativecommons.org/licenses/by/3.0/). 